\title{
KETAHANAN BETON SEMEN PORTLAND COMPOSITE CEMENT (PCC) DI LINGKUNGAN GAMBUT KABUPATEN BENGKALIS
}

\author{
Wandala Adi Putra ${ }^{1}$, Monita Olivia ${ }^{2 *}$, Edy Saputra ${ }^{3}$ \\ ${ }^{1,2}$ Program Studi Magister Teknik Sipil Universitas Riau \\ ${ }^{3}$ Program Studi Magister Teknik Kimia Universitas Riau \\ Email: wandala114111976@gmail.com, *monitaolivia@gmail.com (corresponding author), \\ edysaputra_eng@yahoo.com
}

\begin{abstract}
ABSTRAK
Penelitian ini membahas tentang ketahanan beton menggunakan semen PCC dengan mutu beton rencana $f^{\prime}$ 'cr $15 \mathrm{MPa}$, f'cr $20 \mathrm{MPa}$ dan f'cr $28 \mathrm{MPa}$ melalui proses perawatan menggunakan air normal selama 28 hari yang selanjutnya direndam di lingkungan air gambut dengan $\mathrm{pH}$ berkisar antara 3-3,80 dengan rata-rata $\mathrm{pH}$ 3,44 selama 120 hari di Kabupaten Bengkalis. Adapun penelitian ini memiliki tujuan untuk mengkaji kuat tekan dan porositas beton. Beton dengan menggunakan semen PCC, sampai dengan umur perendaman 120 hari di lingkungan gambut untuk beton dengan kuat tekan rencana $15 \mathrm{MPa}, 20 \mathrm{MPa}$ dan $28 \mathrm{MPa}$ terjadi peningkatan kuat tekan yang signifikan yakni antara $23.4 \% \mathrm{~s} / \mathrm{d} 29.8 \%$. Terkait porositas terjadi sedikit peningkatan pada umur perendaman 28 hari di lingkungan gambut yakni berkisar $0.1-1.2 \%$. Selanjutnya seiring bertambahnya umur perendaman, porositas semakin menurun hingga mencapai $-15.1 \%$ hingga $-27.5 \%$ pada umur 120 hari perendaman di lingkungan gambut. Hal ini mengindikasikan bahwa beton semakin padat. Kuat tekan mempengaruhi porositas dimana semakin besar kuat tekan maka semakin kecil porositas yang terjadi. Dari tiga jenis mutu beton rencana yang diujicobakan, maka f'cr $28 \mathrm{MPa}$ dengan menggunakan semen PCC sangat disarankan untuk digunakan di lingkungan gambut.
\end{abstract}

Kata kunci: Ketahanan beton, PCC, kuat tekan, porositas, lingkungan gambut

\section{ABSTRACT}

This study discusses the properties of concrete using PCC cement with a target strength of $15 \mathrm{MPa}, 20$ $\mathrm{MPa}$ and $28 \mathrm{MPa}$ cured in normal water for 28 days before immersed in a peat water environment with a $\mathrm{pH}$ ranging between 3.00 to 3.80 for 120 days in Bengkalis Regency. The research has the aim to study the compressive strength and porosity of concrete. Concrete using PCC cement, until the immersion age of 120 days in the peat environment for concrete with a compressive strength of $15 \mathrm{MPa}, 20 \mathrm{MPa}$ and $28 \mathrm{MPa}$, there was a significant increase in compressive strength between $23.4 \%$ to $29.8 \%$. There was a slight increase in porosity the immersion age of 28 days in the peat environment, ranging from $0.1 \%$ to $1.2 \%$. Furthermore, as the age of immersion increases, porosity decreases to reach $-15.1 \%$ to $-27.5 \%$ at the age of 120 days of immersion in the peat environment. This indicates that the concrete is getting denser. Compressive strength affects porosity where the greater the compressive strength, the smaller the porosity of the concrete. Of the three types of concrete quality plans that were tested, then the target strength of 28 MPa using PCC cement is highly recommended for structures in the peat environment.

Keywords: concrete resistance, $P C C$, compressive strength, porosity, peat environment

\section{PENDAHULUAN}

Kabupaten Bengkalis terletak di pulau Bengkalis dan berada di pesisir timur Pulau Sumatera. Secara astronomis terletak di antara $2^{\circ} 7^{\prime} 37.2^{\prime \prime}-0^{\circ} 55^{\prime} 33.6^{\prime \prime} \quad$ Lintang Utara dan $100^{\circ} 57^{\prime} 57.6^{\prime \prime}-102^{\circ} 30^{\prime} 25.2^{\prime \prime}$ Bujur Timur memiliki luas $8,403.28 \mathrm{~km}^{2}$ [1] dengan lahan gambut diperkirakan seluas 501,560.33 Ha [2] atau sekitar $59.69 \%$ dari total luas Kabupaten Bengkalis itu sendiri. Gambut di pulau Bengkalis umumnya berupa gambut pantai karena tempat pembentukannya terjadi di daerah dataran rendah sepanjang pantai yang dipengaruhi oleh gelombang pasang-surut. Berdasarkan tipologi, lahan gambut yang ada di
Kabupaten Bengkalis dibagi menjadi lahan bergambut $(0-50 \mathrm{~cm})$, dangkal $(50-100 \mathrm{~cm})$, tengahan $(100-200 \mathrm{~cm})$, gambut dalam $(200-300 \mathrm{~cm})$ dan gambut sangat dalam (lebih besar dari $300 \mathrm{~cm}$ ). Berdasarkan derajat dekomposisinya sebagian besar digolongkan sebagai gambut saprik dengan daya dukung beban rendah [2].

Salah satu sifat kimia tanah gambut pada lokasi ini adalah tingkat kemasaman tanah $\mathrm{pH}<4.5$. Kondisi lahan gambut yang bersifat asam sebagaimana disampaikan di atas disinyalir menjadi salah satu penyebab kerusakan sebagian besar konstruksi beton di Kabupaten Bengkalis khususnya saluran drainase dan konstruksi beton lainnya yang selalu terpapar air gambut. Sifat fisik dan mekanis beton dapat dipengaruhi oleh lingkungan asam yang

Wandala, Ketahanan Beton Semen Portland Composite Cement (PCC) Di Lingkungan Gambut Kabupaten Bengkalis 
menyebabkan beton mengalami kerusakan. Asam menyerang pasta semen sehingga menjadi rusak berupa retak dan hancurnya beton [3]. Kerusakan beton akibat serangan asam dapat mempengaruhi durabilitas beton dalam jangka panjang. Durabilitas beton diartikan ketahanan beton untuk menahan cuaca, serangan kimia, abrasi, dan proses kerusakan akibat lingkungan sehingga beton dapat mempertahankan bentuk asli, kualitas dan masa layan dalam jangka panjang [4].

Setiap tahun Kabupaten Bengkalis mengucurkan dana miliaran rupiah untuk pembangunan saluran drainase dan konstruksi beton lainnya yang senantiasa terpapar air gambut. Dana tersebut pada tahun 2015 digunakan untuk pembangunan saluran drainase sepanjang $3,32 \mathrm{~km}$, pembangunan turap dan pengaman tebing pantai. Apabila dana sebesar itu tidak digunakan dengan baik tanpa mempertimbangkan paparan air gambut dalam perencanaan dan pembangunan konstruksi beton tersebut, maka masa layan dan durabilitas bangunan juga tidak dapat tercapai dalam jangka panjang. Salah satu contoh kekurangan dalam penentuan mutu beton yang tidak didasarkan pada kajian ketahanan di air gambut adalah dengan menggunakan mutu tidak sesuai dengan perencanaan. Seringkali dalam perencanaan saluran drainase menggunakan mutu beton f'c 14,53 MPa (K-175) lebih banyak didasarkan pada faktor ekonomis dan kepraktisan saja.

Penggunaan faktor air semen yang besar pada saat pelaksanaan menyebabkan porositas beton semakin besar sehingga serangan asam lebih cepat merusak beton dan tulangan, finishing beton yang tidak baik kerapkali bagian beton yang keropos saat pengecoran tidak ditangani dengan baik, penggunaan air yang tidak sesuai dengan spesifikasi yang ditentukan, tidak adanya perencanaan masa layan yang baik, tidak adanya pemeliharaan terhadap konstruksi beton yang terpapar air gambut dan lain sebagainya. Akibat hal tersebut tidak jarang ditemukan di Kabupaten Bengkalis banyak saluran drainase maupun konstruksi beton lainnya yang terpapar air gambut mengalami kerusakan parah dalam waktu yang relatif singkat karena spesifikasi konstruksi tidak memenuhi masa layan rencana sehingga berpengaruh di kemudian hari dengan pihak berwajib.

Beberapa pengujian terkait beton di lingkungan gambut yang pernah dilakukan diantaranya oleh Olivia et al. [5] melakukan pengujian terhadap ketahanan mortar di lingkungan asam dengan tipe semen yang berbeda. Kuat tekan mortar normal lebih rendah daripada mortar Ordinary Portland Cement (OPC) yang ditambahkan abu sawit. Penggunaan mortar Portland Composite Cement (PCC) dapat meningkatkan kekuatan mortar yang terendam air gambut. Pandiangan et al. [6] melakukan pengujian ketahanan beton mutu tinggi di lingkungan asam, lalu menyimpulkan bahwa air gambut dengan $\mathrm{pH}$ berkisar 4,00 sampai dengan 5,00 dapat menurunkan kuat tekan beton pada awal.

Tujuan penelitian ini adalah mengkaji kuat tekan dan porositas beton menggunakan semen PCC dengan tiga macam kekuatan yakni 15, 20 dan 28 MPa yang terpapar air gambut selama 120 hari di kanal kabupaten Bengkalis. Korelasi antara kuat tekan dengan porositas beton dengan tiga macam kekuatan tersebut juga turut dibahas.

\section{TINJAUAN PUSTAKA}

\section{Semen Portland Composite (PCC)}

Semen merupakan bahan pengikat yang memiliki senyawa atau zat pengikat hidrolis. Zat-zat perekat dari semen mengandung senyawa kalsium silikat hidrat atau C-S-H yang reaktif bila diberi air sehingga dapat mengikat agregat kasar, agregat halus dan bahan tambah lainnya untuk membentuk massa padat dan keras.

Semen memiliki berbagai jenis/tipe, diantaranya Portland Composite Cement (PCC). Semen komposit ini diproduksi dari penggilingan bubuk semen Portland dengan bahan anorganik lain yang memiliki karakteristik pozzolan, mengandung silikat tinggi, mengandung kapur dan slag dari pembakaran biji besi. Bahan tersebut ditambahkan ke dalam semen sebanyak 6-35\% dari berat semen berdasarkan SNI 15-7064-2004 [7]. Bahan tambah yang digunakan pada semen PCC bertujuan untuk memberikan peningkatan mutu, mempercepat waktu pengerasan, memperbaiki kemudah-pengerjaan, menurunkan porositas, meningkatkan ketahanan terhadap zat perusak di lingkungan agresif. Mineral yang digunakan dapat berupa material reaktif jika diberi air, material pozzolanik, dan kombinasi dari kedua jenis material tersebut [8].

Semen PCC biasanya digunakan sebagai pengganti semen tipe I (OPC) untuk pekerjaan beton, pasangan bata, dan konstruksi yang memerlukan ketahanan dan durabilitas tinggi di lingkungan agresif. Penggunaan Semen PCC (Portland Composite Cement) menghasilkan ketahanan beton maupun mortar yang lebih baik daripada semen OPC dalam lingkungan air laut, asam atau sulfat. Bahan tambah dalam semen akan reaktif saat bertemu dengan produk hidrasi semen, kemudian akan menghasilkan silikat tambahan melalui reaksi lanjutan atau reaksi pozzolanik untuk meningkatkan kuat tekan dan kekedapan beton seperti pada penelitian Susanto et al. [9]. Oleh karena itu semen PCC lebih banyak direkomendasikan untuk konstruksi di lingkungan agresif.

\section{Durabilitas}

Beberapa hal dapat mempengaruhi durabilitas beton, seperti permeabilitas, kerusakan fisik, kimia, biologi akibat lingkungan, cuaca dan kerentanan tulangan baja akibat korosi [10]. Kerusakan fisik berupa abrasi sangat sering dialami beton yang langsung terpapar lingkungan agresif. Selain penyebab fisik kerusakan pada beton, serangan kimiawi juga sangat berpengaruh terhadap kerusakan atau durabilitas beton. Serangan sulfat, serangan asam, alkali dan klorida dalam air laut adalah contohcontoh serangan kimiawi dari lingkungan agresif 
yang dapat mengurangi durabilitas beton. Selain kuat tekan yang tinggi ketahanan beton ataupun mortar di lingkungan agresif, tolak ukur lainnya adalah permeabilitas. Permeabilitas yang rendah dapat meningkatkan ketahanan beton di lingkungan agresif, indikator ini berhubungan dengan porositas dan ukuran pori, serta kemampuan beton meloloskan air melalui pori tersebut.

\section{Beton di Lingkungan Asam}

Lingkungan agresif merupakan lingkungan yang rentan bagi struktur beton untuk mengalami serangan kimia seperti dari ion klorida, ion sulfat, dan ion asam menurut Komite American Concrete Institute atau ACI Committee [11]. Salah satu contoh lingkungan agresif adalah lingkungan asam baik alami seperti gambut atau sulfat, karena memiliki $\mathrm{pH}$ lebih kecil dari $\mathrm{pH}$ air normal.

Beton dapat diserang oleh berbagai asam organik maupun anorganik seperti sulfat, nitrat, klorida, fosfat, asetat, laktat dan lain-lain. Dari berbagai jenis asam tersebut, asam sulfat dianggap sebagai asam yang paling menyebabkan kerusakan beton [12]. Asam sulfat adalah jenis asam kuat yang mudah terionisasi secara sempurna di dalam air dibandingkan dengan jenis asam kuat lainya, sehingga lebih sering dijumpai pada beberapa kandungan air yang bersifat asam seperti air gambut dan hujan asam [13]. Asam sulfat terdapat dalam tanah sebagai hasil oksidasi mineral sulfida seperti pirit, oleh bakteri aerobik yaitu Thiobacillus ferrooxidans [12].

Serangan asam pada beton berupa reaksi ion asam organik pada air gambut dengan produk hidrasi semen atau $\mathrm{Ca}(\mathrm{OH})_{2}$ membentuk gipsum yang mudah larut dalam air. Reaksi lanjutan gipsum dengan kalsium aluminat hidrat menghasilkan ettringite. Apabila dalam beton terdapat ettringite berlebihan, maka akan terjadi disintegrasi matriks beton sehingga terbentuk keropos pada beton yang akan mengurangi kekuatan [14].

\section{Beton di Lingkungan Gambut}

Penelitian terdahulu untuk beton dan mortar di lingkungan gambut telah dilakukan dengan cara merendam benda uji dalam air gambut. Pada lingkungan gambut terdapat asam organik dari hasil pelapukan tumbuhan yang terendam air di daerah rawa atau dataran rendah. Pelapukan tumbuhan tersebut terjadi dalam kondisi anaerob yang menyebabkan terjadinya asam organik. Oleh karena itu air gambut memiliki keasaman tinggi, warna keruh merah kecoklatan seperti karat, dan kandungan bahan organik tinggi [15]. Ion asam organik tersebut tidak hanya terdapat dalam tanah tetapi juga air gambut sehingga beton terendam air gambut sangat rentan mengalami kerusakan lebih cepat. Beton yang dibuat dengan semen OPC lebih mudah rusak di lingkungan gambut karena asam organik menyerang produk hidrasi semen dengan air atau $\mathrm{Ca}(\mathrm{OH})_{2}$ dan hasil reaksi berupa residu tidak bermanfaat bagi beton.
Pada penelitian menggunakan beton semen OPC, PCC, dan OPC-abu sawit yang direndam di kanal gambut memperlihatkan bahwa tambahan abu sawit dalam beton dapat meningkatkan ketahanan karena kuat tekan dan sifat mekanis lain terus meningkat [16]. Beton semen PCC dengan kuat tekan rencana $35 \mathrm{MPa}$ pada penelitian ini juga memperlihatkan peningkatan kuat tekan dan penurunan porositas ebih signifikan dibandingkan beton OPC-abu sawit.

Penelitian Meirisa [17] menggunakan abu sekam padi untuk meningkatkan ketahanan mortar di lingkungan gambut, menggunakan 5\%, 10\% dan 15\% abu sekam sebagai pengganti sebagian semen. Hasil penelitian menunjukkan bahwa penggantian abu sekam maksimum $15 \%$ dapat membantu peningkatan kuat tekan dan penurunan porositas mortar setelah direndam dalam air gambut selama 91 hari.

Penggunaan bubuk kerang darah (Anadara granosa) sebagai bahan tambah pada mortar menggunakan semen OPC untuk aplikasi di air gambut telah dikaji oleh Rahmayani et al. [18]. Pada penelitian ini, bubuk kerang dijadikan bahan tambah dan bukan bahan pengganti semen. Kuat tekan mortar bubuk kulit kerang terus bertambah dengan waktu perendaman. Hal ini dipengaruhi oleh kandungan $\mathrm{CaO}$ pada bubuk kulit kerang dapat menetralisir asam pada air gambut dan penambahan bubuk kulit kerang sebagai filler membuat mortar menjadi lebih kedap. Nilai porositas mortar bubuk kulit kerang terus menurun pada rendaman air gambut. Hal ini membuktikan bahwa penambahan bubuk kulit kerang mengurangi angka pori pada mortar sehingga mortar menjadi lebih kedap.

\section{METODE PENELITIAN}

\section{Bahan Penelitian}

Pada penelitian ini menggunakan semen PCC yang diproduksi oleh PT. Semen Padang, Sumatera Barat dengan karakteristik pada Tabel 1.

Agregat kasar dan halus yang dipakai berasal dari Kabupaten Tanjung Balai Karimun Provinsi Kepulauan Riau karena sering digunakan oleh pelaksana konstruksi di Bengkalis. Pengujian karakterisik material beton meliputi analisis saringan agregat halus dan kasar [19], berat jenis dan penyerapan agregat halus dan kasar [20,21], kadar air agregat [22], dan keausan agregat dengan mesin abrasi Los Angeles [23].

Tabel 1. Karakteristik Portland Cement Composite (PCC) produksi PT. Semen Padang

\begin{tabular}{|c|c|c|}
\hline No. & Pengujian & Hasil Uji \\
\hline \multicolumn{3}{|c|}{ Komposisi kimia } \\
\hline 1. & Bagian tak larut & $8,12 \%$ \\
\hline 2. & Magnesium oksida $(\mathrm{MgO})$ & $0,63 \%$ \\
\hline 3. & Sulfur trioksida $\left(\mathrm{SO}_{3}\right)$ & $1,78 \%$ \\
\hline 4. & Hilang pijar & $4,60 \%$ \\
\hline 5. & Total Alkali $\left(\mathrm{Na}_{2} \mathrm{O}+0.658 \mathrm{~K}_{2} \mathrm{O}\right)$ & $0,52 \%$ \\
\hline \multicolumn{3}{|c|}{ Komposisi fisika } \\
\hline 6. & Kehalusan dengan alat Blaine & $361 \mathrm{~m}^{2} / \mathrm{kg}$ \\
\hline
\end{tabular}




\begin{tabular}{|c|l|c|}
\hline 7. & Kekekalan pemuaian dengan & $0,08 \%$ \\
8. & Autoclave & \\
& Waktu Pengikatan dengan alat & \\
& Vicat & 145 menit \\
& $\quad$ Ikat awal & 228 menit \\
9. & Ikat akhir & $182 \mathrm{~kg} / \mathrm{cm}^{2}$ \\
& Kekuatan tekan (mortar) & $246 \mathrm{~kg} / \mathrm{cm}^{2}$ \\
& 3 hari & $335 \mathrm{~kg} / \mathrm{cm}^{2}$ \\
& 7 hari & $71,08 \%$ \\
\hline
\end{tabular}

Berdasarkan hasil pengujian karakteristik material, agregat kasar, agregat halus dan air telah memenuhi spesifikasi dan standar sebagai material penyusun beton. Untuk agregat kasar memiliki berat jenis SSD 2,62, absorbsi 0,38\% dan kadar air 0,25\%. Agregat halus memiliki berat jenis SSD 2,55, modulus kehalusan 2,89, absorbsi $1,11 \%$ dan kadar air 1,65\%. Gambar 1 menunjukkan agregat kasar dan agregat halus pada penelitian ini.
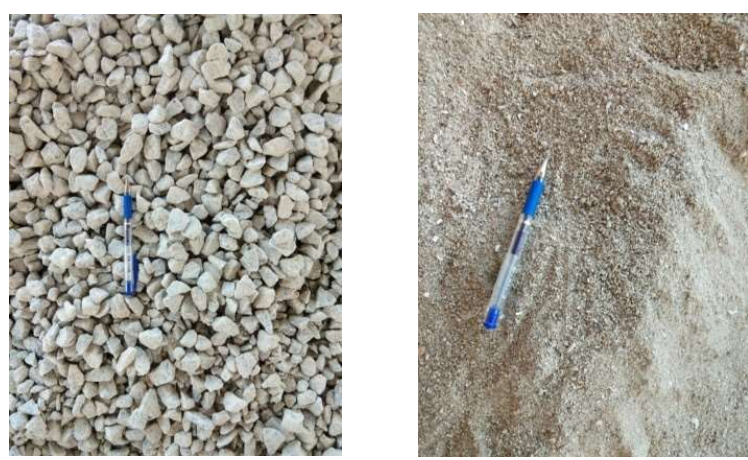

Gambar 1. Agregat kasar dan halus asal Tanjung Balai Karimun

Air normal untuk pencampur beton dan air normal untuk proses curing digunakan air hujan. Air yang digunakan pada campuran beton harus bersih, tidak terdapat kandungan asam, zat organik, alkali, minyak atau bahan lain yang merusak beton. Secara garis besar air yang digunakan air tawar dan bisa diminum.

\section{Pelaksanaan Pembuatan Benda Uji}

a) Perencanaan Pembuatan Benda Uji

Benda uji pada penelitian ini sebanyak 72 .

Untuk pengujian kuat tekan menggunakan beton berbentuk silinder berdiameter $150 \mathrm{~mm}$ dengan ketinggian $300 \mathrm{~mm}$. Pada pengujian porositas menggunakan beton berbentuk silinder dengan diameter $150 \mathrm{~mm}$, tinggi $150 \mathrm{~mm}$.

Tabel 2. Rencana pembuatan benda uji

\begin{tabular}{|c|c|c|c|}
\hline No. & $\begin{array}{c}\text { Pengujian dan } \\
\text { kuat tekan } \\
\text { rencana }\end{array}$ & $\begin{array}{c}\text { Umur } \\
\text { rendam } \\
\text { (hari) }\end{array}$ & $\begin{array}{c}\text { Jumlah } \\
\text { benda } \\
\text { uji }\end{array}$ \\
\hline 1. & Kuat tekan & & \\
& $-15 \mathrm{MPa}$ & $0,28,91,120$ & 12 \\
& $-20 \mathrm{MPa}$ & $0,28,91,120$ & 12 \\
& $-28 \mathrm{MPa}$ & $0,28,91,120$ & 12 \\
\hline 2. & Porositas & & \\
& $-15 \mathrm{MPa}$ & $0,28,91,120$ & 12 \\
& $-20 \mathrm{MPa}$ & $0,28,91,120$ & 12 \\
\hline
\end{tabular}

\begin{tabular}{|l|l|l|l|}
\hline & $-28 \mathrm{MPa}$ & $0,28,91,120$ & 12 \\
\hline \multicolumn{3}{|c|}{ Jumlah } & 72 \\
\hline
\end{tabular}

b) Perencanaan Mix Design Beton

Hasil pengujian properties agregat digunakan untuk memperoleh data-data dalam perencanaan komposisi beton. Perencanaan campuran beton mengikuti SNI 03-2834-2000 [24]. Komposisi bahan pembentuk beton disajikan pada Tabel 3 .

Tabel 3. Komposisi beton per $\mathrm{m}^{3}$

\begin{tabular}{|c|c|c|c|c|}
\hline $\begin{array}{c}\text { Kuat } \\
\text { tekan } \\
\text { rencana }\end{array}$ & $\begin{array}{c}\text { Air } \\
(\mathbf{k g})\end{array}$ & $\begin{array}{c}\text { Semen } \\
(\mathbf{k g})\end{array}$ & $\begin{array}{c}\text { Agregat } \\
\text { halus } \\
(\mathbf{k g})\end{array}$ & $\begin{array}{c}\text { Agregat } \\
\text { kasar } \\
(\mathbf{k g})\end{array}$ \\
\hline $15 \mathrm{MPa}$ & 194,84 & 311,93 & 847,21 & 1008,02 \\
\hline $20 \mathrm{MPa}$ & 189,38 & 331,93 & 831,36 & 1009,33 \\
\hline $28 \mathrm{MPa}$ & 172,53 & 403,22 & 779,96 & 1006,29 \\
\hline
\end{tabular}

\section{c) Proses Pembuatan Benda Uji}

Material penyusun beton yang digunakan ditimbang sesuai komposisi yang telah dihitung, selanjutnya material tersebut dicampur dengan menggunakan mesin pengaduk sampai campuran merata, kelecekannya cukup dan tampak campurannya homogen. Setelah pencampuran selesai dilakukan pengukuran slump untuk menentukan workability campuran dan diukur tinggi jatuh campuran tersebut (Gambar 2). Kemudian campuran beton dimasukkan ke cetakan secara bertahap sebanyak tiga lapis yang lebih kurang sama tebalnya. Tiap lapisan dipadatkan menggunakan tongkat pemadat sebanyak 25 kali tusukan secara merata. Cetakan akan dibuka setelah \pm 24 jam berikutnya.

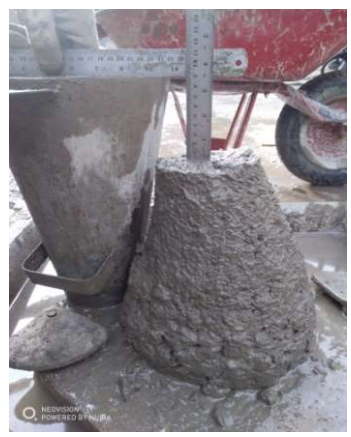

Gambar 2. Pengukuran slump beton

d) Perawatan benda uji (curing)

Pelaksanaan perawatan bertujuan agar proses hidrasi semen dapat berlangsung dengan sempurna selama 28 hari, setelah itu benda uji direndam di lingkungan gambut. Pada perawatan di laboratorium sebelum perendaman di lingkungan gambut, benda uji direndam menggunakan air hujan yang telah diendapkan (Gambar 3). 


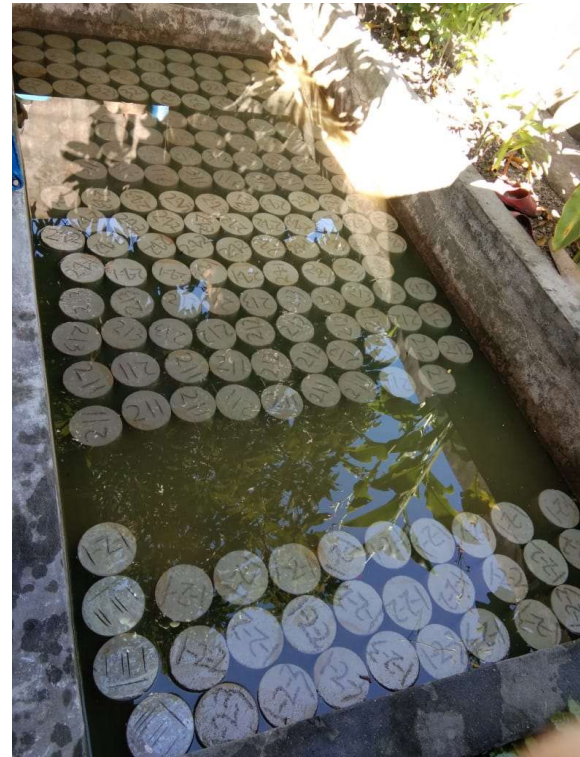

Gambar 3. Benda uji direndam di kolam perendaman.

Adapun proses curing bertujuan agar proses hidrasi dapat berlangsung dengan sempurna. Penduduk di Kabupaten Bengkalis umumnya menggunakan air hujan karena sumber air bersih lain tidak banyak tersedia. Gambar 4 menunjukkan proses perawatan benda uji saluran drainase di kota Bengkalis sampai umur 120 hari.

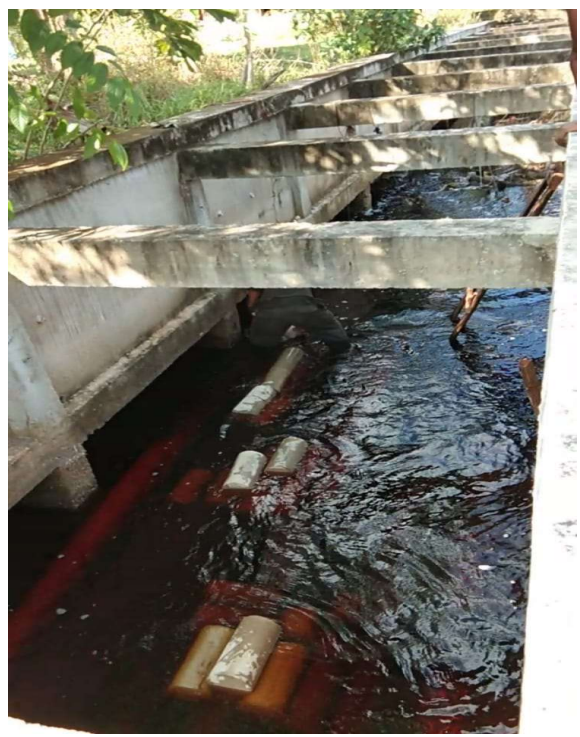

Gambar 4. Benda uji direndam dalam saluran air gambut. Pelaksanaan pengujian

Pengujian yang dilakukan meliputi pengujian kuat tekan dan pengujian porositas dimana masingmasing pengujian menggunakan tiga benda uji. Umur pengujian dilakukan pada $0,28,91$ dan 120 hari perendaman di lingkungan gambut. Penggunaan alat Universal Testing Machine (UTM) untuk pengujian kuat tekan mengacu pada standar SNI 03-1974-1990 [25]. Sementara itu, untuk pengujian porositas menggunakan standar yang mengacu pada ASTM C 642 [26].

\section{HASIL DAN PEMBAHASAN}

\section{Kuat tekan}

Gambar 3 menunjukkan perubahan kuat tekan beton dengan mutu 15, 20 dan 28 MPa yang direndam selama 120 hari air kanal. Seiring bertambahnya umur perendaman benda uji di lingkungan gambut hingga mencapai umur 120 hari setelah dilakukannya proses curing terlihat bahwa umumnya kuat tekan semakin meningkat antara $23.4 \%$ s/d $29.8 \%$. Peningkatan kuat tekan ini dimungkinkan akibat adanya bahan tambahan yang terkandung dalam semen PCC. Lambatnya reaksi pozzolanik pada semen PCC menyebabkan lamanya pembentukan Kalsium Silikat Hidrat pada beton. Hasil pengujian kuat tekan pada benda uji menggunakan semen PCC disajikan pada Gambar 5 berikut.

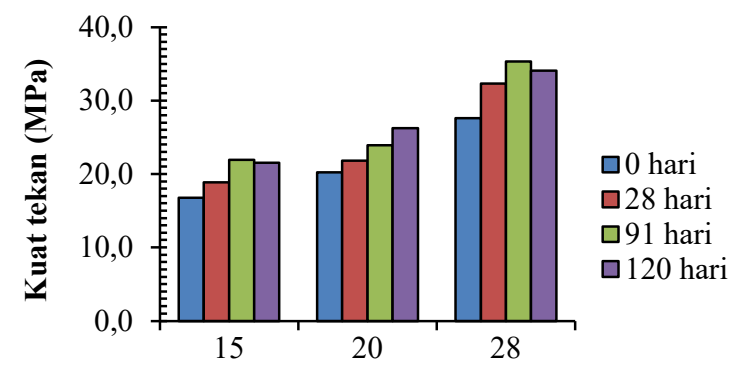

Kuat tekan rencana (MPa)

Gambar 5. Hasil pengujian kuat tekan beton

Pada umur 28 hari, benda uji dengan f'cr 28 MPa mengalami peningkatan kuat tekan terbesar yakni $17.1 \%$, diikuti dengan f'cr $15 \mathrm{MPa}$ sebesar $12.7 \%$ dan terkecil terjadi pada f'cr $20 \mathrm{MPa}$ sebesar $7.8 \%$. Pada umur 91 hari perendaman di lingkungan gambut masih terjadi peningkatan kuat tekan untuk ketiga jenis kuat tekan rencana, dimana peningkatan terbesar terjadi pada benda uji dengan f'cr $15 \mathrm{MPa}$ sebesar $31.0 \%$, diikuti dengan f'cr $28 \mathrm{MPa}$ sebesar $27.9 \%$ dan yang terkecil terjadi pada f'cr $20 \mathrm{MPa}$ yakni sebesar $18.3 \%$.

Berbeda halnya pada umur 120 hari perendaman di lingkungan gambut, untuk benda uji dengan f'cr $15 \mathrm{MPa}$ dan f'cr $28 \mathrm{MPa}$ terjadi penurunan kuat tekan menjadi $28.5 \%$ untuk f'cr 15 MPa dan $23.4 \%$ untuk f' cr $28 \mathrm{MPa}$. Untuk benda uji dengan f'cr $20 \mathrm{MPa}$ masih terjadi peningkatan kuat tekan menjadi $29.8 \%$. Seluruh persentase kuat tekan tesebut terhitung dari kuat tekan umur 0 hari perendaman di lingkungan gambut dengan kata lain dihitung berdasarkan kuat tekan setelah selesai proses perawatan atau curing dan sebelum benda uji ditempatkan di lingkungan gambut.

Penggunaan berbagai macam jenis semen maupun bahan tambahan lainnya telah diteliti untuk mengetahui sifat-sifat beton maupun mortar terpapar air gambut. Sebagai gambaran bahwa semen OPC (Ordinary Portland Cement) mengalami peningkatan kuat tekan bila direndam di dalam larutan aquades seiring bertambahnya umur dikarenakan proses 
hidrasi yang berjalan dengan baik pada semen. Namun tidak demikian halnya untuk beton ataupun mortar dengan semen OPC yang direndam di lingkungan gambut. Beton yang direndam di air gambut secara signifikan akan mengalami peningkatan porositas, penurunan kepadatan dan kuat tekan. Berdasarkan pengujian ini terlihat bahwa penggunaan semen PCC memberikan kontribusi yang lebih baik dalam hal ketahanan beton di lingkungan gambut khususnya terkait kuat tekan beton. Hal ini dikarenakan bahan tambah bereaksi dengan hasil hidrasi semen melalui proses pozzolanik memberikan silikat tambahan (C-S-H) yang dapat memperbaiki kekedapan dan kuat tekan beton. Temuan serupa dikonfirmasi oleh Olivia et al. 2014 [27].

Penggunaan material pozzolanik merupakan salah satu solusi untuk meningkatkan ketahanan beton di lingkungan gambut. Salah satu cara adalah menggunakan Portland Composite Cement (PCC) yang memiliki kandungan pozzolan untuk mengurangi kerentanan beton di lingkungan agresif seperti gambut. Penggunaan Semen PCC (Portland Composite Cement) menghasilkan ketahanan beton maupun mortar yang lebih baik daripada semen OPC.

\section{Porositas}

Pengujian porositas pada benda uji menggunakan semen PCC mengalami sedikit peningkatan porositas pada umur 28 hari berkisar $0.1 \% \mathrm{~s} / \mathrm{d} 1.2 \%$. Selanjutnya porositas semakin menurun hingga mencapai $-15.1 \% \mathrm{~s} / \mathrm{d}-27.5 \%$ pada umur 120 hari. Pengujian porositas pada benda uji menggunakan semen PCC disajikan pada Gambar 6.

Pada umur 28 hari terjadi sedikit peningkatan porositas untuk tiga jenis kuat tekan rencana, dimana untuk f'cr $15 \mathrm{MPa}$ mengalami peningkatan porositas sebesar $0.8 \%$, f'cr $20 \mathrm{MPa}$ sebesar $0.1 \%$ dan f'cr 28 MPa sebesar 1.2\%. Pada umur 91 hari perendaman, porositas untuk tiga jenis kuat tekan rencana mengalami penurunan sebesar $-5.5 \%$ untuk f'cr 15 $\mathrm{MPa},-6.2 \%$ untuk f' cr $20 \mathrm{MPa}$ dan $-13.3 \%$ untuk f'cr $28 \mathrm{MPa}$. Begitu pula halnya dengan umur perendaman 120 hari, penurunan porositas masih terus terjadi dimana penurunan porositas terbesar terjadi pada kuat tekan rencana f'cr $28 \mathrm{MPa}$ sebesar $27.5 \%$, diikuti oleh f'cr $20 \mathrm{MPa}$ sebesar $-18.3 \%$ dan penurunan terkecil terjadi pada f'cr $15 \mathrm{MPa}$ sebesar $15.1 \%$.

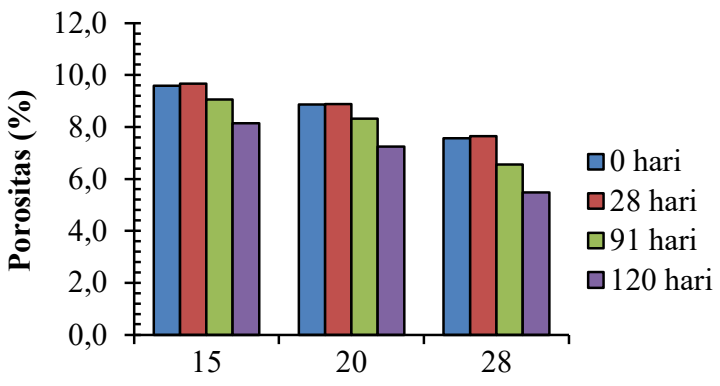

Kuat tekan rencana (MPa)

Gambar 6. Hasil pengujian porositas beton
Secara ringkas dapat disampaikan bahwa penurunan porositas f'cr $28 \mathrm{MPa}>\mathrm{f}^{\prime} \mathrm{cr} 20 \mathrm{MPa}>\mathrm{f}$ 'cr $15 \mathrm{MPa}$. Hal ini mengindikasikan bahwa semakin besar kuat tekan maka semakin besar pula penurunan porositas yang terjadi. Seluruh persentase porositas tesebut terhitung dari porositas umur 0 hari perendaman di lingkungan gambut dengan kata lain dihitung berdasarkan porositas setelah selesai proses perawatan atau curing dan sebelum benda uji ditempatkan di lingkungan gambut.

Porositas beton terus mengalami penurunan setelah direndam di air gambut memperlihatkan bahwa proses hidrasi terus terjadi meskipun lingkungan asam memiliki asam organik yang terus menerus dapat merusak beton. Perendaman beton PCC di lapangan dengan penurunan porositas sampai umur 120 hari menunjukkan ketahanan beton dari semen PCC yang lebih baik untuk lingkungan agresif. Perbedaan nilai porositas antara beton dengan mutu rendah (15 $\mathrm{MPa})$ dan mutu tinggi (28 $\mathrm{MPa})$ dapat dijadikan indikator pemilihan material yang cocok untuk aplikasi di lapangan.

Penurunan porositas menunjukkan bahwa benda uji semakin padat dan kedap. Hal ini dimungkinkan akibat adanya material pozzolanik yang terkandung dalam semen PCC. Material pozzolanik memberikan efek tahan terhadap serangan asam organik dan mencegah terjadinya peningkatan porositas pada beton akibat perendaman di lingkungan gambut. Dengan demikian maka semen PCC dapat dianggap memberikan dampak yang lebih baik dalam hal ketahanan beton di lingkungan gambut. Temuan ini juga sejalan dengan penelitian yang dihasilkan oleh Olivia et al. 2016 [28].

\section{Hubungan kuat tekan dan porositas}

Berdasarkan hasil pengujian kuat tekan dan pengujian porositas maka dapat dilihat hubungan antara kuat tekan dan porositas pada Gambar 6 . Hubungan antara kuat tekan dan porositas perlu dibuat untuk menunjukkan bahwa perbandingan antara kuat tekan dengan porositas memiliki hubungan proporsional, yakni semakin tinggi kuat tekan maka akan semakin rendah porositas, dan sebaliknya.

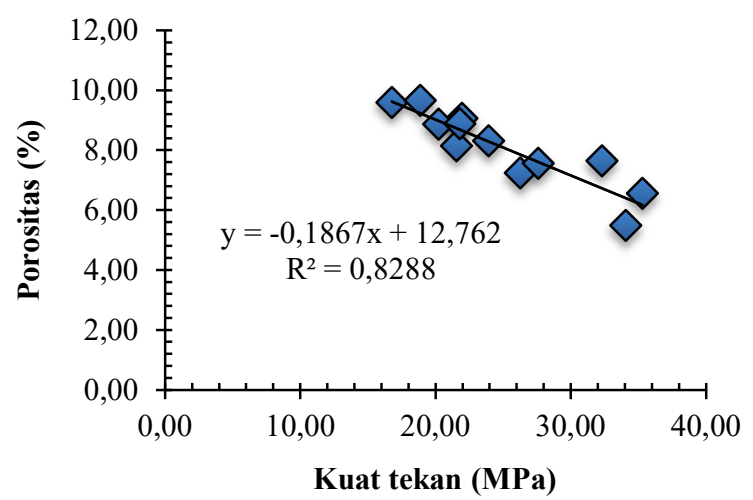

Gambar 7. Hubungan antara kuat tekan dan porositas 
Pada Gambar 7, dapat dilihat bahwa porositas berbanding terbalik dengan kuat tekan. Korelasi kuat tekan dan porositas berbanding lurus dengan $\mathrm{R}^{2}=$ 0.828. Hal ini menguatkan teori umum bahwa semakin tinggi kuat tekan maka semakin kecil porositas.

Berdasarkan tiga jenis kuat tekan rencana maka f'cr $28 \mathrm{MPa}$ akan sangat tepat jika digunakan sebagai beton di lingkungan gambut. Porositas yang kecil menyebabkan semakin kecil pula peluang serangan asam organik yang terjadi di dalam inti beton sehingga umur konstruksi beton akan menjadi lebih lama. Selain daripada itu penggunaan semen PCC juga mengurangi larutnya material pada sisi permukaan beton.

Untuk konstruksi beton di lingkungan gambut sangat disarankan untuk menggunakan kuat tekan rencana f'cr $28 \mathrm{MPa}$ dimana mutu beton ini dianggap lebih mampu bertahan dari serangan asam organik yang ada di lingkungan gambut. Hal ini dikarenakan f'cr $28 \mathrm{MPa}$ memiliki kuat tekan yang tinggi dan porositas yang kecil.

\section{KESIMPULAN}

Berdasarkan hasil pengujian beton dengan berbagai mutu menggunakan semen PCC dapat dilihat bahwa kekuatan memiliki pengaruh terhadap kekuatan beton. Semakin tinggi kekuatan beton akan semakin baik ketahanannya di lingkungan gambut. Disamping itu penggunaan semen PCC akan memberikan kontribusi dalam meningkatkan kekuatan dan ketahanan beton di lingkungan gambut akibat adanya material pozzolanik yang terdapat pada semen PCC. Porositas beton juga memiliki trend sama dengan kuat tekan, yakni semakin tinggi mutu beton maka semakin rendah porositas. Semakin tinggi kuat tekan maka semakin kecil porositas sehingga semakin besar ketahanan konstruksi beton itu dari serangan asam organik yang terdapat di lingkungan gambut. Untuk konstruksi beton di lingkungan gambut sangat disarankan untuk menggunakan kuat tekan rencana f'cr $28 \mathrm{MPa}$ dimana mutu beton ini dianggap lebih mampu bertahan dari serangan asam organik yang ada di lingkungan gambut. Hal ini dikarenakan f'cr $28 \mathrm{MPa}$ memiliki kuat tekan yang tinggi dan porositas yang kecil.

\section{DAFTAR PUSTAKA}

[1] Badan Pusat Statistik Kabupaten Bengkalis, 2019, Kabupaten Bengkalis Dalam Angka 2019.

[2] Nasrul, B, Penyebaran dan Potensi Lahan Gambut di Kabupaten Bengkalis untuk Pengembangan Pertanian, Jurnal Agroteknologi, Vol. 1 No. 1, Agustus 2010.

[3] Yusuf, Y, Pengaruh Penambahan Abu Terbang (Fly Ash) terhadap Kuat Tekan Mortar Semen PCC serta Analisis Air Laut yang Digunakan untuk Perendaman. Tugas Akhir Mahasiswa Universitas Lampung, 2013.

[4] Mehta, P.K, Monteiro, P.J.M, Concrete Microstructure, Properties and Material. New York: Mc Graw-Hill.

[5] Olivia, M, Hutapea, U.A, Sitompul, I.R, Darmayanti, L, Kamaldi, A, Djauhari, Z, Properties of plain and blended cements exposed to sulfuric acid solution and acidic peat water: a preliminary study. The $6^{\text {th }}$ International Conference of Asian Concrete Federation, 2014.

[6] Pandiangan, J.A, Olivia, M, Darmayanti, L, Ketahanan beton mutu tinggi di lingkungan asam, Jurnal Online Mahasiswa (JOM) Bidang Teknik dan Sains, Vol. 1, No. 1, 2014.

[7] SNI, SNI 15-7064-2004: Semen Portland Komposit, Jakarta: Badan Standardisasi Nasional, 2004.

[8] Mulyono, T, Teknologi Beton, Yogyakarta: Penerbit Andi, 2007.

[9] Susanto, D, Djauhari, Z, Olivia, M, Karakteristik beton menggunakan Portland Composite Cement (PCC) dan Silica Fume untuk aplikasi struktur di daerah laut, Jurnal Rekayasa Sipil, Vol. 15, No. 1, 2019.

[10] Lobo, C.L, New Perspective on Concrete Durability, Concrete in Focus Magazine, 2007.

[11] ACI Committee 201, Guide to Durable Concrete, Farmington Hills: American Concrete Institute, 2008.

[12] Allahverdi, A, Acidic corrosion of hydrated cement based materials-Part 2. Kinetics of the phenomenon and mathematical models. Ceramics Silikaty, Vol. 44, No. 4, 2000.

[13] Song, X, Development and perfornace of class F fly ash based geopolymer concrete against sulphuric acid attack. PhD Thesis, University of New South Wales, 2007.

[14] Sebayang, S, Pengaruh abu terbang sebagai pengganti sejumlah semen tipe $\mathrm{V}$ pada beton mutu tinggi, Jurnal Teknik Sipil Vol. 6, No. 2, 2006.

[15] Eglinton, M, Resistance of concrete to destructive agencies. In Hewlett, P.C. (ed). Lea's Chemistry of Cement and Concrete. Amsterdam: Elsevier Science \& Technology Books.

[16] Olivia, M, Pradana, T, Sitompul, I.R, Properties of plain and blended cement concrete immersed in acidic peat water canal, Procedia Engineering, Vol. 171, 2017.

[17] Ednor, M, Sitompul, I.R., Olivia, M, Kuat tekan dan perubahan berat mortar menggunakan bahan tambah abu sekam padi (rice husk ash) di air gambut, Prosiding Konferensi Nasional Teknik Sipil dan Perencanaan (KN-TSP), 2017

[18] Rahmayani, I.S, Saputra, E, Olivia, M, Kuat tekan dan porositas mortar menggunakan bahan tambah bubuk kulit kerang di air gambut, Prosiding Konferensi Nasional Teknik Sipil dan Perencanaan (KN-TSP), 2017 
[19] Badan Standarisasi Nasional, 1991, Metode Pengujian Tentang Analisis Saringan Agregat Halus dan Kasar, SNI 03-1968-1991.

[20] Badan Standarisasi Nasional, 1991, Metode Pengujian Berat Jenis dan Penyerapan Agregat Halus, SNI 03-1970-1991.

[21] Badan Standarisasi Nasional, 1991, Metode Pengujian Berat Jenis dan Penyerapan Agregat Kasar, SNI 03-1969-1991.

[22] Badan Standarisasi Nasional, 1991, Metode Pengujian Kadar Air Agregat, SNI 03-19711991.

[23] Badan Standarisasi Nasional, 1991, Metode Pengujian Keausan Agregat dengan Mesin Abrasi Los Angeles, SNI 03-2417-1991.

[24] Badan Standarisasi Nasional, 2000, Tata Cara Pembuatan Rencana Campuran Beton Normal, SNI 03-2834-2000.

[25] Badan Standarisasi Nasional, 1990, Metode Pengujian Kuat Tekan Beton, SNI 03-19741990.

[26] ASTM, 2006, Standard Test Methods Density, Absorption, and Void in Hardened Concrete, ASTM C 642.

[27] Monita Olivia, Uli A Hutapea, Iskandar R Sitompul, Lita Darmayanti, Alfian Kamaldi and Zulfikar Djauhari, 2014, Resistance of Plain and Blended Cements Exposed to Sulfiric Acid Solution and Acidic Peat Water: A Preliminary Study, 2014, The $6^{\text {th }}$ International Conference of Asian Concrete Federation, Seoul, Korea.

[28] Monita Olivia, Tomy Pradana, Iskandar Romey Sitompul, 2016, Properties of Plain and Blended Cement Concrete Immersed in an Acidic Peat Water Canal, Sustainable Civil Engineering Structure and Construction Material 2016, SCESCM 2016. 